\title{
THE EFFECT OF STUDENTS' PERSONAL PHOTOGRAPH AS MEDIA IN TEACHING WRITING ABILITY IN SMPN 1 WAWOTOBI
}

\author{
${ }^{\text {a }}$ Hasriati, ${ }^{\text {b }}$ Asri Nofa Rama \\ ${ }^{a, b}$ English Department, Teacher Training and Educational Faculty, \\ Lakidende University \\ e-mail: suci.hasriati911@gmail.com
}

\begin{abstract}
The purpose of study is to examine whether significant differences exist in students' pretest and posttest writing ability as a result of experiencing student's personal photograph as media and to examine whether significant differences in students' test scores exist between those attending personal photograph as media and those experiencing conventional instruction without media at the eighth students grade in SMPN 1 Wawotobi. The population of this research was the entire the eighth grade students of SMPN 1 Wawotobi who enrolled in academic year 2016/2017. The data were obtained from students' pre-test and posttest scores. The pre-test was given before the treatment applied and the posttest is given after the treatment finished. The finding revealed that significant differences exist in students' pretest and posttest writing ability as a result of experiencing instruction using personal photograph as media, $\mathrm{p}(.000)<0.05$. The finding also indicated that significant differences in students' test scores exist between those attending personal photograph as media and those experiencing conventional instruction $\mathrm{p}(.000)<0.05$. In light of all these findings, students' personal photograph significantly affected students' writing ability.
\end{abstract}

Keywords: Personal Photograph, Writing Ability, Effect 


\section{INTRODUCTION}

Writing is one of fundamental skills in learning English. It relates to process of one's output of language learning in which he or she uses his or her understanding of the language input in written form, specifically expressing his or her ideas. Nevertheless, in Indonesia, nowadays writing skill of English Foreign Language (EFL) students has become a problem. Writing as productive skill is considered as the most difficult skill for some students to learn. Because clearly in producing a good essay needs some skills such as the correct usage of grammar, vocabulary, part of speech, spelling and many more (Singh, et al., 2017).

Meanwhile, in reality, most of English department students at Lakidende University have encountered some problems to write successfully, such as they do not know how to express the ideas on the paper, they tend to translate the sentences from their mother tongue and this leads to making ungrammatical errors, they often find it difficult to express themselves through the use of appropriate words or grammar due to the lack of vocabulary, and they have no idea how to start their writing. Based on these problems, it demands the teacher to find media to teach writing to students that it may attract their interest to learn writing. Teaching media are used to enable the students to achieve the learning objectives more effectively and interestingly (Kundu, 2017).

By means of teaching media in the classroom, it may help students to find out ideas, make difficult subjects more understandable, and hold student's attention to remember important ideas. It means that a good media that is may facilitate the students to produce ideas in which it may help them in starting their writing. One of media that is appropriate to apply in teaching writing subject is visual learning aids.

A number of studies have examined the effectiveness of picture as teaching media, but they merely focus on examining picture as teaching media, this present study intends to apply student's personal photograph as media in teaching writing ability, particularly to examine significant differences exist in students' perception before they are taught using personal photograph and students' perception after they are taught using personal photograph. For this reason, the researcher tries to conduct a research by means of student's personal photograph on teaching writing personal recount text.

\section{METHODS}

This research employed quantitative method research. It is selected for this study because the researcher proposes to examine the effect of student's personal photograph in teaching writing ability. Therefore, the design of this research was quasiexperimental which use a non-equivalent (pretest and post-test) control-group design. The population of this research was the entire the eighth grade students of SMPN 1 Wawotobi who are enrolled in academic year 2016/2017. The samples of this study were VIII.A and VIII.B. The instrument is used in this research is written test. The test required the students to write about recount text, particularly personal recount text at least 80-100 words. The writing test was the same in use on pre-test and post-test. In addition, to analyze the data, this study applied Paired Sample T-test and Independent Samples T-Test. 


\section{Writing Skill}

Writing skill was defined by Jacobs, Zinkgraf, Wormuth, F. Hartfiel and Hughey (1981:60) as "the ability of students in mastery of five aspects such as content, organization, vocabulary, language use, and mechanic". In addition, according to White (2007) writing is a thinking process. In another point of view, writing is not regarded as product, but it is a recursive process (Harmer, 2007: 113;Gebhard, 2000: 222; Brown, 2001: 334; Alwasilah \& Alwasilah, 2007: 6; and Johnson,2000: 288 as cited in Fauzi, 2012). Based on the theories above, the writer states that writing is one of activities that are considered difficult enough in learning language. There are some requirements that should be fulfilled in order to compose a good form of writing, specifically content, organization, and language use. Because writing is a process of thinking, certainly it involves our mind to organize ideas, background knowledge, or information for generating a good product of writing. In addition, process of writing is not only about putting down the result of thought. Here, its process involved all stages of the text composing, from prewriting, drafting, revising, and editing.

\section{Photographs as Media in Teaching Writing}

In previous section, it was explained that in composing a good writing, the students should master grammar and they also should be able to organize their ideas. In addition, in writing activity, the students need to think and image anything before starting to write. In writing classroom employing visual media, Kendall and Khuon (2006: 111 as cited in Fauzi, 2010) instructed their students to write sense by using images. This effort, they believe, can explore students' ideas and the students will be conscious to study mental images direction in the pieces of their writing. Photograph as one source of pictures might really be used as teaching media I writing class. From this point of view, using student's personal photograph on writing personal recount text is possible.

By and large, human retention on details of a precise event is considerably low. Roediger, (2005, as cited in Fauzi) clarifies that retrieval of what has been experienced or stored information in brain is crucial thing in remembering but human will never be able to really remember. Some students, when they try to write events they already experienced, found difficulty to gain exact memory about that. To cope with such problem, visual media like photograph can be a solution because as Ahola (2004) states that photographs usually capture important moments in our lives. It means that photographs can be used as recorder of past events in which it may help students to memorize about events, places, and people in detail.

Therefore, photograph as captured picture by camera that usually shows details and realistic exposure is representative to mediate visual literacy. Brown, et al (2007) believed that photograph can be used to reinforce impression, add new facts, or provide meanings to abstraction that consequently increase visual literacy. Photograph as one of visual media types can improve fluency of understanding through elaboration of structure or organization and enhance retention (Arsyad, 2009: 91). By such improvement writing recount text are consequently supported by enhanced retention and elaborated structure of mind. Moreover, recount text retells past events or activities in line with photograph that can capture interconnected images of objects and setting within.

In teaching writing recount text, retention is very influential because recount text constitutes sequence of events and even consists of evaluative comments or conclusion 
about the events from the writer (Emilia, 2010). Ability to write recount text that emphasizes the description of events can be enhanced by opaque picture that presents detail visual information enclosing environment and setting where the picture created. Characteristics of opaque picture, photograph in this case, can help students writing recount text because Gerlach and Ely (1980:280) identify that opaque picture really fit creative writing, by decoding visual information, explaining a sequential process, and valuable teaching by students' stories photo of their own. It means that photograph may help students to compose their creative writing, by pooling some information from the photograph then putting them down into a piece of writing.

\section{FINDINGS}

Table 4.1 The Result of Paired Samples T-Test Paired Samples Test

\begin{tabular}{|c|c|c|c|c|c|c|c|c|c|}
\hline & \multicolumn{5}{|c|}{ Paired Differences } & \multirow[b]{3}{*}{$t$} & \multirow[b]{3}{*}{ df } & \multirow{3}{*}{$\begin{array}{l}\text { Sig. (2- } \\
\text { tailed) }\end{array}$} \\
\hline & & \multirow[b]{2}{*}{ Mean } & \multirow{2}{*}{$\begin{array}{c}\text { Std. } \\
\text { Deviation }\end{array}$} & \multirow{2}{*}{$\begin{array}{l}\text { Std. Error } \\
\text { Mean }\end{array}$} & \multicolumn{2}{|c|}{$\begin{array}{c}95 \% \text { Confidence Interval } \\
\text { of the Difference }\end{array}$} & & & \\
\hline & & & & & Lower & Upper & & & \\
\hline Pair 1 & $\begin{array}{l}\text { Pretest - } \\
\text { Posttest }\end{array}$ & 19.500 & 8.184 & 1.404 & 22.356 & 16.644 & 13.893 & 33 & .000 \\
\hline
\end{tabular}

Since t-test belongs to parametric statistics, however, it is vital that the assumption of t-test (parametric statistic) be examined first. It was found that none of these assumptions has been violated, in turn, it warrants the application of this analysis. In addition, to prove whether the hypothesis $\mathrm{H} 0$ and $\mathrm{H} 1$ was accepted or not, the probability value (sig. 2 tailed) of Paired Sample T-test must be divided into 2 to get probability value (sig. 1 tailed).

A statistical analysis of Paired Sample T-test was conducted to compare students' writing ability scores before applying the students' personal photograph and after applying the students' personal photograph. There was a significant difference in the mean scores for pre-test $(\mathrm{M}=57.41, \mathrm{SD}=8.743)$ and post-test $(\mathrm{M}=76.91, \mathrm{SD}=$ $6.127)$ conditions; $\mathrm{t}(33)=13.893, \mathrm{p}(.000)<0.05$. These results indicated that significant differences existed in students' pretest and posttest writing ability as a result of experiencing student's personal photograph as media. These results indicated that posttest scores are significantly higher than pre-test scores, a significant gain of 19.3 points.

4.2 Group Statistics of Independent Samples Group Statistics

\begin{tabular}{|ll|r|r|r|r|}
\hline & Class & $\mathrm{N}$ & Mean & Std. Deviation & Std. Error Mean \\
\hline NGainScore & 1 & 34 & 31.80 & 11.892 & 2.378 \\
& 2 & 34 & 10.60 & 13.096 & 2.619 \\
\hline
\end{tabular}


Based on result of the table above, it pointed out mean score of N-Gain in experiment class was 31.80 with its standard deviation 11.892. On the contrary, it pointed out mean score of N-Gain in control class was 10.60 with its standard deviation 13.096. This result revealed that significant differences in students' test scores existed between those attending personal photograph as media and those experiencing conventional instruction without media. In this case, students' writijg ability who taught by means of personal photograph significantly increased compare with those who taught through conventional teaching instruction.

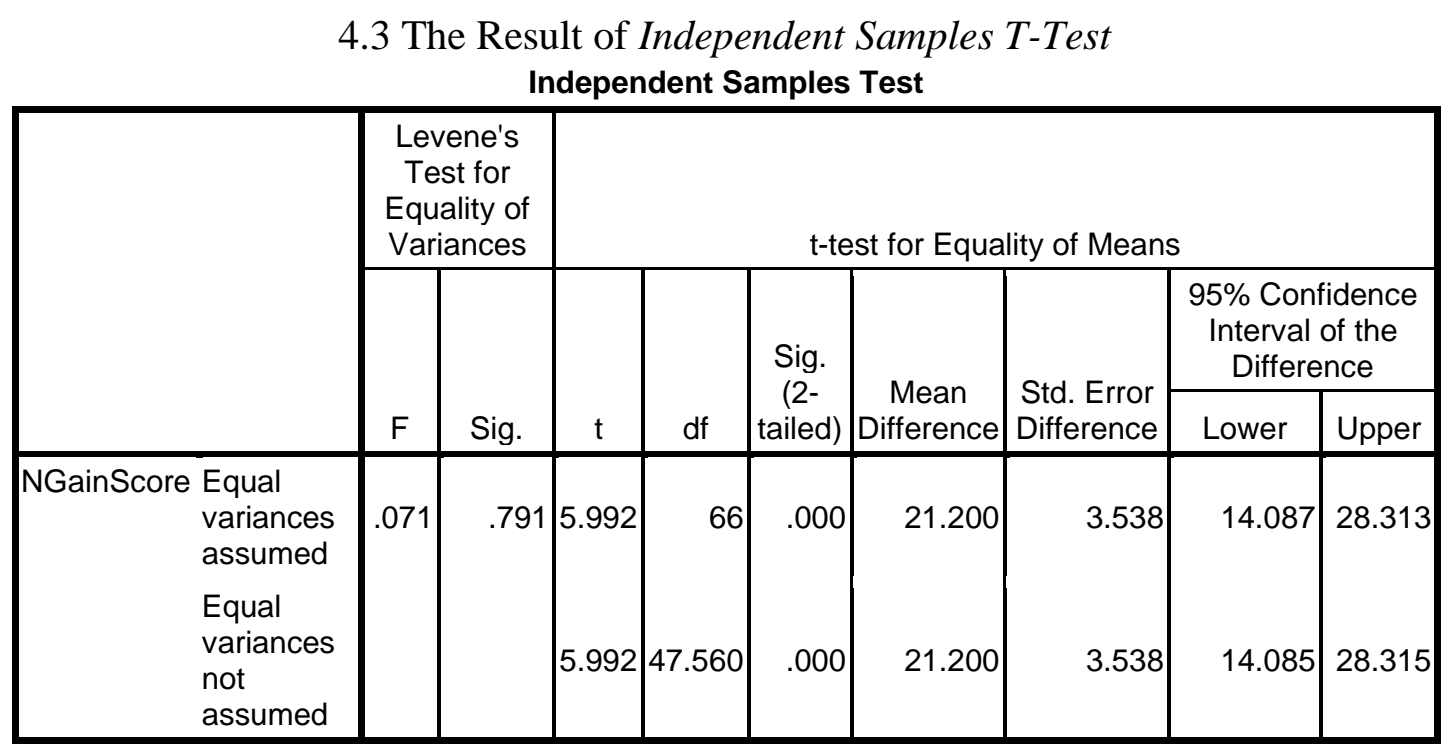

An Independent Samples T-Test is conducted to examine significant differences in students' test scores existed between those attending personal photograph as media and those experiencing conventional instruction without media. The result indicated that there was a significant difference in the mean scores between N-Gain students in experiment class and $\mathrm{N}$-Gain students in control class $(\mathrm{M}=31.80, \mathrm{SD}=11.892)$ and students were taught using conventional media $(\mathrm{M}=10.60, \mathrm{SD}=13.096)$ conditions; $\mathrm{t}$ $(48)=5.992, \mathrm{p}(.000)<0.05$.

The result indicated that the probability value ( $\mathrm{p}$ value) was less than the level of significance $(\mathrm{p}<0.05)$, in this case $(.000<0.05)$. In addition, since this research applied directional hypotheses, therefore the probability value (sig. 2 tailed) of Independent Samples T-Test must be divided into 2 to get probability value (sig. 1 tailed). Thus, $\mathrm{p}(.000)$ divided into 2 became $(.000<0.05)$. It means that the null hypothesis (H0) was rejected and alternative hypothesis $(\mathrm{H} 1)$ was accepted. On other words, this result indicated that a significant differences in students' test scores existed between those attending personal photograph as media and those experiencing conventional instruction without media. Indeed, it can be concluded that teaching writing ability using the personal photograph indicated a significant effect on students' writing ability.

\section{DISCUSSION}

The findings of this research provided information about the entire parts to use the personal photograph as teaching media in writing ability. This section purposed to compare the present findings to previous researches, in which these researches also 
examine the scientific approach in different English skills. This section are divided into two parts, namely to examine whether significant differences exist in students' pretest and posttest writing ability as a result of experiencing student's personal photograph as media and to examine whether significant differences in students' test scores exist between those attending personal photograph as media and those experiencing conventional instruction without media.

\section{\# Do significant differences exist in students' pretest and posttest writing ability as result of experiencing media using student's personal photograph as media?}

First and foremost, this research examined whether or not significant differences exist in students' pretest and posttest writing ability as a result of experiencing students' personal photograph as media at VIII.A class of SMPN 1 Wawotobi. The findings revealed that there is significant differences exist in students' pre-test and posttest writing ability as a result of experiencing instruction using personal photograph. On other words, there is a significant score difference on students' writing ability before and after they are taught by using the personal photograph as teaching media. These findings suggested that personal photograph affect students' writing ability due to it engage student who did not always respond to writing class, it reinforce the material, and it connect students with their own environment because every photograph is created in a particular time, places and events. This finding is consistent with the result of a research by Pelani (2015), that the use of personal photograph was significantly effective in students' writing ability.

Furthermore, Arsyad (2009) mentions the advantages of using personal photograph in teaching, namely photograph can give a clear explanation in presenting message and information so that it can improve the process and the results of teaching and learning, photograph can improve and stimulate the students so that it can motivate them to study, and photograph can handle the problems of restrictiveness in terms of sense, place, and time; in this case in it can record a special moment in which it happened in particular time and place.

\section{\# Do significant differences in students' test scores exist between those attending student's personal photograph as media and those experiencing conventional instruction without media?}

The last, this research examined whether significant differences in students' test scores exist between those attending student's personal photograph as media and those experiencing conventional instruction without media at VIII.A class (experiment class) and VIII.B class (control class) of SMPN 1 Wawotobi. The findings of the research revealed significant differences in students' test scores exist between those attending student's personal photograph as media and those experiencing conventional instruction without media. Besides, mean score of students' writing ability in experiment class were higher than mean score of students' writing ability in control class. This means that students' writing ability that are taught using the personal photograph was more increased than students' writing ability that are taught using the conventional teaching instruction without media. Indeed, it can be concluded that teaching writing ability using the personal phoograph indicated a significant effect on students' writing ability. 
This finding is consistent with the result of a research by Safitri (2017), that teaching writing ability by using the personal photograph was more effective that the conventional teaching instruction without media. She strongly suggested that the English teachers should use the personal photograph as one of medium that can be applied in teaching writing ability.

\section{CONCLUSION}

The findings of this study led to some crucial conclusions as follows:

1. There is significant differences exist in students' pre-test and posttest writing ability as a result of experiencing instruction using personal photograph. On other words, there is a significant score difference on students' writing ability before and after they are taught by using the personal photograph as teaching media. The result of posttest in which the students are taught through the students' personal photograph showed that the mean score is higher than pre-test, i.e. $76.68<57.38$.

2. There are significant differences in students' test scores exist between those attending student's personal photograph as media and those experiencing conventional instruction without media. Besides, mean score of students' writing ability in experiment class were higher than mean score of students' writing ability in control class. This means that students' writing ability that are taught using the personal photograph was more increased than students' writing ability that are taught using the conventional teaching instruction without media.

\section{REFERENCES}

Ahola, Steven Kenneth. 2004. Using Personal Photograph to Spark Narrative Writing. The Internet TESL Journal, Vol. X. Kansai Gaidai University. Japan. Retrieved from http://iteslj.org/Lessons/Ahola-PersonalPhotographs.html on 13th June 2019.

Arsyad, Azhar. 2009. Media Pembelajaran. Jakarta: Raja Grafindo Persada

Brown, J.W. et al. 2007. Technology, Media and Methods. United States of America: McGraw-Hill, Inc.

Emilia, Emi. 2010. Teaching Writing: Developing Critical Learner. Bandung: Rizqi Press.

Fauzi, E. M. 2012. Fostering Students' Skill of Writing Recount Text Aided by Photography. Apple31 Journal. Volume 1, No. 1, November 2012. Retrieved from http://e-journal.stkipsiliwangi.ac.id/index.php/apple31_journal/article/ download/63/35 on 18th April 2019. Free

Gerlach, Vernon S. and Ely, Donald P. 1980. Teaching and Media: A Systematic Approach. Englewood Cliffs: Prentice Hall

Harmer, Jeremy. 2004. The Practice of English Language Teaching (3rd Edition). Longman. Retrieved from http:///BookFi.org on 15th June 2017. Free 
Jacobs, Zinkgraf, Wormuth, F. Hartfiel, and Hughey. 1981. Testing ESL Composition Profile: A Practical Approach Rowley, MA: Newbury House Publisher.

Kundu, J. 2017. Use of Teaching Aids in Language Teaching. IJRAR- International Journal of Research and Analytical Reviews. 4(3), 247-250.

Navidinia, H., \&Ozhan, A. R. 2019. Using pictures in EFL classrooms: Exploring its potential contribution for developing students' writing skill. Research Gate Journal. DOI: 10.21315/apjee2018.33.1

Safitri, Hilda. 2017. The Use of Personal Photograph as Media in Teaching Writing Descriptive The Second Grade Students of MTS Negeri Gowa. English Educational Department. Alauddin State Islamic University of Makassar.

Singh, C. K. S., Mei, T. P., Abdullah, M. S., Othman, W. M., \& Mostafa, N. A. 2017. ESL learners' perspectives on the use of picture series in teaching guided writing. International Journal of Academic Research in Progressive Education and Development. 6(4), 74-89.

Pelani, Gustain. 2015. The Effect of Personal Photograph on Students' Writing Quantity in Descriptive Text (A Quasi-Experimental Study on the Second Year Students of SMAN 8 Bengkulu). Journal of Linguistics and Language Teaching. 2(1), 1-11.

White, Ron. 2007. Writing Advanced. Oxford University Press.

Wright, Andrew. 2017. Pictures for Language Learning: Cambridge Handbooks for Language Teacher. Cambridge University Press. Retrieved from http://BookFi.org on 13th June 2019. Freeulsen Books. 